\title{
Antimicrobial and demelanizing activity of Ganoderma lucidum extract, $p$-hydroxybenzoic and cinnamic acids and their synthetic acetylated glucuronide methyl esters
}

Sandrina A. Heleno ${ }^{a, b}$, Isabel C.F.R. Ferreira, ${ }^{b, *}$, Ana P. Esteves ${ }^{a}$, Ana Ćirićc ${ }^{c}$ Jasmina Glamočlija $^{\mathrm{c}}$, Anabela Martins ${ }^{\mathrm{b}}$, Marina Sokovićc ${ }^{\mathrm{c}}$, Maria João R.P. Queiroz ${ }^{\mathrm{a}}$

${ }^{a}$ Centro de Química, Universidade do Minho, Campus de Gualtar 4710-057 Braga, Portugal.

${ }^{b}$ Centro de Investigação de Montanha (CIMO), ESA, Instituto Politécnico de Bragança, Campus de Santa Apolónia, apartado 1172, 5301-854 Bragança, Portugal.

${ }^{c}$ University of Belgrade, Institute for Biological Research "Siniša Stanković", Department of Plant Physiology, Bulevar Despota Stefana 142, 11000 Belgrade, Serbia.

* Author to whom correspondence should be addressed (Isabel C.F.R. Ferreira; e-mail: iferreira@ipb.pt; telephone+351-273-303219; fax +351-273-325405). 


\begin{abstract}
Mushroom extracts or isolated compounds may be useful in the search of new potent antimicrobial agents. Herein, it is described the synthesis of protected (acetylated) glucuronide derivatives of $p$-hydroxybenzoic and cinnamic acids, two compounds identified in the medicinal mushroom Ganoderma lucidum. Their antimicrobial and demelanizing activities were evaluated and compared to the parent acids and G. lucidum extract. $p$-Hydroxybenzoic and cinnamic acids, as also their protected glucuronide derivatives revealed high antimicrobial (antibacterial and antifungal) activity, even better than the one showed by commercial standards. Despite the variation in the order of parent acids and the protected glucuronide derivatives, their antimicrobial activity was always higher than the one revealed by the extract. Nevertheless, the extract was the only one with demelanizing activity against $A$. niger. The acetylated glucuronide derivatives could be deprotected to obtain glucuronide metabolites, which circulate in the human organism as products of the metabolism of the parent compounds.
\end{abstract}

Keywords: Ganoderma lucidum; p-hydroxybenzoic acid; cinnamic acid; Acetylated glucuronides; Chemical synthesis; Antimicrobial activity. 


\section{Introduction}

Nature has been a source of medicinal agents for thousands of years. During the last three decades the problem of antibiotic resistance has emerged. Bacterial and fungal pathogens have evolved numerous defense mechanisms against antimicrobial agents, and nowadays, the need to discover new and more potent of these agents as accessories or alternatives to antibiotic therapy is stronger. Currently, natural compounds are on the focus of some biotechnological companies that are looking for new antimicrobial drugs (Butler, 2004; Lam, 2007). Mushrooms are rich sources of bioactive compounds with an enormous variety of chemical structures. In this respect, mushrooms isolated compounds could be useful in the search of new potent antimicrobial agents (Alves et al., 2012).

There are available in literature some studies reporting antimicrobial activity of different extracts of Ganoderma lucidum (Curtis) P. Karst from India (Sheena et al., 2003; Quereshi et al., 2010) and China (Gao et al., 2005). This species is one of the most famous traditional medicinal mushrooms, being used as functional food and in preventive medicines, mostly in the form of extracts with an annual global market value of over \$1.5 billion (Sullivan et al., 2006; Pala and Wani, 2011).

Otherwise, the antimicrobial activity of some phenolic compounds has been described (Lou et al., 2012; Orhan et al., 2010; Alves et al., 2013). p-Hydroxybenzoic acid was the most abundant phenolic acid found in wild G. lucidum from Portugal, as well as cinnamic acid (0.58 and $0.28 \mathrm{mg} / 100 \mathrm{~g}$ dry weight, respectively; Heleno et al., 2012). Furthermore, these compounds are present in several other mushrooms species (Barros et al., 2009).

Dietary phenolic compounds are widely considered to contribute to health benefits in humans. However, little is known about their bioactive forms in vivo and the 
mechanisms by which they may contribute toward disease prevention. Moreover, many studies on the biological effects of phenolic compounds have ignored the question of their achievable concentrations in the circulation after ingestion as well as the possibility of metabolism (Rechner et al., 2002). There is accumulating evidence suggesting that phenolic compounds are rapidly metabolized in the human organism. Glucuronidation appears as one of the most prevalent metabolic pathways for phenolic compounds in humans (Rechner et al., 2002). Despite the large data concerning the antimicrobial effects of phenolic acids (Lou et al., 2012; Orhan et al., 2010; Alves et al., 2013), studies dealing with the antimicrobial properties of their metabolites or derivatives are scarce due to the fact that most of these compounds are not commercially available.

The present work aims at contributing to the knowledge of the mechanisms involved in the antimicrobial properties of phenolic compounds, namely phenolic acids and precursors, usually present in mushrooms. With that goal, the antimicrobial activity of G. lucidum extract, $p$-hydroxybenzoic and cinnamic acids and their acetylated glucuronide derivatives (protected glucuronides), prepared by chemical synthesis, was evaluated and compared.

\section{Materials and methods}

\subsection{Wild mushroom}

Samples of Ganoderma lucidum (Curtis) P. Karst. were collected in Bragança (Northeast Portugal) in July 2011. After taxonomic identification of the sporocarps (Phillips, 1981; Hall et al., 2003; Oria de Rueda, 2007), specimens were deposited at the herbarium of Escola Superior Agrária of Instituto Politécnico de Bragança under the number BRESA-g101-2011. Fruiting bodies were further separated from spores using a 
scalpel, lyophilised (FreeZone 4.5 model 7750031, Labconco, Kansas, USA), and reduced to a fine dried powder (20 mesh).

\subsection{Preparation of the extract}

The lyophilized G. lucidum sample ( $\sim 10 \mathrm{~g})$ was extracted with methanol $(250 \mathrm{~mL})$ at $-20{ }^{\circ} \mathrm{C}$ for $6 \mathrm{~h}$. The extract was sonificated for $15 \mathrm{~min}$, centrifuged at $4000 \mathrm{~g}$ for $10 \mathrm{~min}$ and filtered through Whatman No.4 paper. The residue was then re-extracted with three additional $150 \mathrm{~mL}$ portions of methanol. The combined extracts were evaporated (rotary evaporator Büchi R-210; Flawil, Switzerland) at $40{ }^{\circ} \mathrm{C}$ to dryness.

\subsection{Compounds identified in Ganoderma lucidum}

$p$-Hydroxybenzoic and cinnamic acids are two of the compounds identified in $G$. lucidum (Heleno et al., 2012). For the antimicrobial assays, these compounds were purchased from Sigma (St. Louis, MO, USA).

2.4. Synthesis of acetylated glucuronide derivatives (protected forms of $p$ hydroxybenzoic and cinnamic acids glucuronides)

\subsubsection{2,3,4-tri-O-acetyl-1-p-hydroxybenzoyl-D-glucuronic acid methyl ester (HAGP).}

p-Hydroxybenzoic acid (0.100 g, $0.724 \mathrm{mmol})$, acetobromo- $\alpha$-D-glucuronic acid methyl ester $(0.574 \mathrm{~g}, 1.44 \mathrm{mmol})$ and potassium carbonate $(0.100 \mathrm{~g}, 0.724 \mathrm{mmol})$ were dissolved in $10 \mathrm{~mL}$ of DMSO under argon and the mixture was stirred for $24 \mathrm{~h}$. The reaction mixture was diluted with $50 \mathrm{~mL}$ of ethyl acetate and then washed with water $(7 \times 10 \mathrm{~mL})$. The organic layer was dried over $\mathrm{MgSO}_{4}$ and the solvent was evaporated. The product obtained was purified by a column chromatography using silica gel $60 \mathrm{~A}$ (60-200 micron) and a mixture of ether/petroleum ether $(60 / 40, \mathrm{v} / \mathrm{v})$ as eluent. The 
product was isolated as a white solid $(0.123 \mathrm{~g}, 38 \%)$. m.p. $=125.9-126.2{ }^{\circ} \mathrm{C} .{ }^{1} \mathrm{H}$ NMR $\left(300 \mathrm{MHz}, \mathrm{CDCl}_{3}\right): \delta=2.00(\mathrm{~s}, 3 \mathrm{H}), 2.06(\mathrm{~s}, 3 \mathrm{H}), 2.07(\mathrm{~s}, 3 \mathrm{H}), 3.73(\mathrm{~s}, 3 \mathrm{H}), 4.30(\mathrm{~d}, J=$ $9.6 \mathrm{~Hz}, 1 \mathrm{H}), 5.29(\mathrm{t}, J=9.2 \mathrm{~Hz}, 1 \mathrm{H}), 5.34(\mathrm{dd}, J=9.2$ and $7.6 \mathrm{~Hz}, 1 \mathrm{H}), 5.42(\mathrm{t}, J=$ $9.2 \mathrm{~Hz}, 1 \mathrm{H}), 5.94(\mathrm{~d}, J=7.6 \mathrm{~Hz}, 1 \mathrm{H}), 6.80(\mathrm{~d}, J=8.8 \mathrm{~Hz}, 2 \mathrm{H}), 7.81(\mathrm{~d}, J=8.8 \mathrm{~Hz}, 2 \mathrm{H})$ ${ }^{(*)}{ }^{13} \mathrm{C}$ NMR (75.4 MHz, $\mathrm{CDCl}_{3}$ ): 20.47 (OAc), 20.53 (OAc), 20.58 (OAc), 53.19 (OMe), $69.11(\mathrm{CH}), 69.94(\mathrm{CH}), 71.58(\mathrm{CH}), 72.77(\mathrm{CH}), 91.63(\mathrm{CH}), 115.41(2 \times \mathrm{CH})$, $119.95(\mathrm{C}), 132.58(2 \times \mathrm{CH}), 161.28(\mathrm{C}), 163.99(\mathrm{C}=\mathrm{O}), 167.53(\mathrm{C}=\mathrm{O}), 169.45(\mathrm{C}=\mathrm{O})$, $169.56(\mathrm{C}=\mathrm{O}), 169.91(\mathrm{C}=\mathrm{O})$. HRMS (ESI-TOF) calcd. for $\mathrm{C}_{20} \mathrm{H}_{22} \mathrm{O}_{12}\left(\mathrm{M}^{+}+\mathrm{Na}\right)$ 477.1004, found 477.0995.

(*) The proton of the $\mathrm{OH}$ group was not detected in the proton nmr spectrum.

\subsubsection{2,3,4-tri-O-acetyl-1-cinnamoyl-D-glucuronic acid methyl ester (CAGP).}

Cinnamic acid (0.100 g, $0.675 \mathrm{mmol})$, acetobromo- $\alpha$-D-glucuronic acid methyl ester $(0.268 \mathrm{~g}, 0.675 \mathrm{mmol})$ and potassium carbonate $(0.140 \mathrm{~g}, 1.01 \mathrm{mmol})$ were dissolved in $10 \mathrm{~mL}$ of DMSO under argon and the mixture was stirred for $24 \mathrm{~h}$. The reaction mixture was diluted with $50 \mathrm{~mL}$ of ethyl acetate and then washed with water $(7 \times 10 \mathrm{~mL})$. The organic layer was dried over $\mathrm{MgSO}_{4}$ and the solvent was evaporated. The product obtained was purified by a column chromatography using silica gel 60A (60-200 micron) and a mixture of ether/petroleum ether $(50 / 50, \mathrm{v} / \mathrm{v})$ as eluent. The product was isolated as a white solid $(0.100 \mathrm{~g}, 32 \%) . \mathrm{m} . \mathrm{p}=169.8-170.2{ }^{\circ} \mathrm{C} .{ }^{1} \mathrm{H}$ NMR $(300 \mathrm{MHz}$, $\left.\mathrm{CDCl}_{3}\right): \delta=2.04(\mathrm{~s}, 3 \mathrm{H}), 2.060(\mathrm{~s}, 3 \mathrm{H}), 2.063(\mathrm{~s}, 3 \mathrm{H}), 3.75(\mathrm{~s}, 3 \mathrm{H}), 4.25(\mathrm{~d}, J=9.6 \mathrm{~Hz}$, $1 \mathrm{H}), 5.27(\mathrm{dd}, J=9.2$ and $7.6 \mathrm{~Hz}, 1 \mathrm{H}), 5.31(\mathrm{t}, J=9.2 \mathrm{~Hz}, 1 \mathrm{H}), 5.38(\mathrm{t}, J=9.2 \mathrm{~Hz}, 1 \mathrm{H})$, $5.92(\mathrm{~d}, J=8.0 \mathrm{~Hz}, 1 \mathrm{H}), 6.42(\mathrm{~d}, J=16.0 \mathrm{~Hz}, 1 \mathrm{H}), 7.41-7.43(\mathrm{~m}, 3 \mathrm{H}), 7.53-7.56(\mathrm{~m}, 2 \mathrm{H})$, $7.78(\mathrm{~d}, J=16.0 \mathrm{~Hz}, 1 \mathrm{H}) .{ }^{13} \mathrm{C} \mathrm{NMR}\left(75.4 \mathrm{MHz}, \mathrm{CDCl}_{3}\right): 20.48$ (OAc), 20.55 (OAc), 20.58 (OAc), 53.02 (OMe), $69.05(\mathrm{CH}), 70.12(\mathrm{CH}), 71.82(\mathrm{CH}), 73.06(\mathrm{CH}), 91.57$ 
$(\mathrm{CH}), 116.08(\mathrm{CH}), 128.43(2 \times \mathrm{CH}), 129.00(2 \times \mathrm{CH}), 130.99(\mathrm{CH}), 133.82(\mathrm{C}), 147.66$

$(\mathrm{CH}), 164.51(\mathrm{C}=\mathrm{O}), 166.80(\mathrm{C}=\mathrm{O}), 169.25(\mathrm{C}=\mathrm{O}), 169.42(\mathrm{C}=\mathrm{O}), 169.90(\mathrm{C}=\mathrm{O})$.

HRMS (ESI-TOF) calcd. for $\mathrm{C}_{22} \mathrm{H}_{24} \mathrm{O}_{11}\left(\mathrm{M}^{+}+\mathrm{Na}\right)$ 487.1211, found 487.1212.

\subsection{Antimicrobial activity}

2.5.1. Antibacterial activity. The Gram-positive bacteria Staphylococcus aureus (ATCC 6538), Bacillus cereus (clinical isolate), Listeria monocytogenes (NCTC 7973), and Micrococcus flavus (ATCC 10240), and the Gram-negative bacteria Pseudomonas aeruginosa (ATCC 27853), Escherichia coli (ATCC 35210), Salmonella typhimurium (ATCC 13311), and Enterobacter cloacae (human isolate), were used. The organisms were obtained from the Mycological Laboratory, Department of Plant Physiology, Institute for Biological Research "Siniša Stanković", Belgrade, Serbia. The antibacterial assay was carried out by a microdilution method (CSLI, 2006; Tsukatani et al., 2012) in order to determine the antibacterial activity of extract/compounds tested against the human pathogenic bacteria. The bacterial suspensions were adjusted with sterile saline to a concentration of $1.0 \times 10^{5} \mathrm{CFU} / \mathrm{mL}$. Dilutions of the inocula were cultured on solid medium to verify the absence of contamination and to check the validity of the inoculum.

The minimum inhibitory and bactericidal concentrations (MICs and MBCs) were determined using 96-well microtitre plates by microdilution test. The bacterial suspension was adjusted with sterile saline to a concentration of $1.0 \times 10^{5} \mathrm{CFU} / \mathrm{mL}$. Mushroom extract/compounds were dissolved in 5\% DMSO solution containing $0.1 \%$ Tween $80(\mathrm{v} / \mathrm{v})(10 \mathrm{mg} / \mathrm{mL})$ and added in Tryptic Soy broth (TSB) medium (100 $\mu \mathrm{L})$ with bacterial inoculum $\left(1.0 \times 10^{4} \mathrm{CFU}\right.$ per well) to achieve the wanted concentrations (0.005-3 $\mathrm{mg} / \mathrm{mL}$ for extract and $0.003-0.25 \mathrm{mg} / \mathrm{mL}$ for compounds). The lowest 
concentrations without visible growth (at the binocular microscope) were defined as concentrations that completely inhibited bacterial growth (MICs). The MICs obtained from the susceptibility testing of various bacteria to tested extracts were determined also by a colorimetric microbial viability assay based on reduction of a INT color and compared with positive control for each bacterial strains (CSLI, 2006; Tsukatani et al., 2012). The MBCs were determined by serial sub-cultivation of $2 \mu \mathrm{L}$ into microtitre plates containing $100 \mu \mathrm{L}$ of broth per well and further incubation for $24 \mathrm{~h}$. The lowest concentration with no visible growth was defined as the MBC, indicating $99.5 \%$ killing of the original inoculum. The optical density of each well was measured at a wavelength of $655 \mathrm{~nm}$ by Microplate manager 4.0 (Bio-Rad Laboratories) and compared with a blank and the positive control. Streptomycin (Sigma P 7794) and Ampicillin (Panfarma, Belgrade, Serbia) were used as positive controls $(1 \mathrm{mg} / \mathrm{mL}$ in sterile physiological saline). Five percent DMSO was used as a negative control.

2.5.2. Antifungal activity. Aspergillus fumigatus (human isolate), Aspergillus versicolor (ATCC 11730), Aspergillus ochraceus (ATCC 12066), Aspergillus niger (ATCC 6275), Trichoderma viride (IAM 5061), Penicillium funiculosum (ATCC 36839), Penicillium ochrochloron (ATCC 9112) and Penicillium verrucosum var. cyclopium (food isolate), were used. The organisms were obtained from the Mycological Laboratory, Department of Plant Physiology, Institute for Biological Research "Siniša Stanković", Belgrade, Serbia. The micromycetes were maintained on malt agar and the cultures stored at $4{ }^{\circ} \mathrm{C}$ and sub-cultured once a month. In order to investigate the antifungal activity of mushroom extract/compounds, a modified microdilution technique was used (Hanel et al., 1988; Espinel-Ingroff, 2001). The fungal spores were washed from the surface of agar plates with sterile $0.85 \%$ saline containing $0.1 \%$ Tween $80(\mathrm{v} / \mathrm{v})$. The spore 
suspension was adjusted with sterile saline to a concentration of approximately $1.0 \times 10^{5}$ in a final volume of $100 \mu \mathrm{L}$ per well. Dilutions of the inocula were cultured on solid malt agar to verify the absence of contamination and to check the validity of the inoculum. Minimum inhibitory concentration (MIC) determinations were performed by a serial dilution technique using 96-well microtiter plates. Extract and compounds were dissolved in 5\% DMSO solution containing $0.1 \%$ Tween $80(\mathrm{v} / \mathrm{v})(10 \mathrm{mg} / \mathrm{mL})$ and added in broth Malt medium with inoculum $(0.005-3 \mathrm{mg} / \mathrm{mL}$ for extract and $0.003-0.25$ $\mathrm{mg} / \mathrm{mL}$ for compounds). The lowest concentrations without visible growth (at the binocular microscope) were defined as MICs. The fungicidal concentrations (MFCs) were determined by serial subcultivation of a $2 \mu$ of tested compounds dissolved in medium and inoculated for $72 \mathrm{~h}$, into microtiter plates containing $100 \mu \mathrm{L}$ of broth per well and further incubation $72 \mathrm{~h}$ at $28{ }^{\circ} \mathrm{C}$. The lowest concentration with no visible growth was defined as MFC indicating 99.5\% killing of the original inoculum. DMSO was used as a negative control, and commercial fungicides, bifonazole (Srbolek, Belgrade, Serbia) and ketoconazole (Zorkapharma, Šabac, Serbia), were used as positive controls ( $1-3000 \mu \mathrm{g} / \mathrm{mL})$.

\subsection{Demelanizing activity using micromycetes}

All microfungi tested for antifungal activity of G. lucidum extract were used to evaluate extract/compounds demelanizing activity. The micromycetes were maintained on malt agar and the cultures were stored at $4{ }^{\circ} \mathrm{C}$; 96-well microtiter plates were used. The fungal spores were washed from the surface of agar plates with sterile $0.85 \%$ saline containing $0.1 \%$ Tween $80(\mathrm{v} / \mathrm{v})$. The spore suspension was adjusted with sterile saline to an approximate concentration of $1.0 \times 10^{5}$ in a final volume of $100 \mu \mathrm{L} /$ well. Dilutions of the inocula were cultured on malt agar to verify the absence of contamination and to 
check the validity of the inoculum. Determination of minimum demelanizing concentrations (MDC) was performed by a serial dilution technique. The extract/compounds were dissolved in 5\% DMSO solution containing $0.1 \%$ Tween 80 $(\mathrm{v} / \mathrm{v})(10 \mathrm{mg} / \mathrm{mL})$ and added in broth Malt medium with inoculum $(0.005-3 \mathrm{mg} / \mathrm{mL}$ for extract and $0.003-0.25 \mathrm{mg} / \mathrm{ml}$ for compounds). The microplates were incubated at Rotary shaker $(160 \mathrm{rpm})$ for $72 \mathrm{~h}$ at $28^{\circ} \mathrm{C}$. A sample of mycelium was taken from the periphery of a colony grown on Malt extract medium enriched with different concentrations of tested extract. The samples were dried and fixed with lactophenol and observed under a light microscope (Mikroskop DMLS Typ 020518 500. Leica, Wetzlar. Neubauer Zählkammer. Eppendorf, Hamburg, Germany) to examine structural abnormalities (Heleno et al., 2013). The lowest concentration that provoked demelanization of fungal hyphae and conidia was determined as MDC. Samples from the control plate without added extracts were also stained and observed. Solution of 5\% DMSO was used as a negative control.

\subsection{Statistical analysis}

All the assays were carried out in triplicate and the results are expressed as mean values and standard deviation (SD). The results were analyzed using one-way analysis of variance (ANOVA) followed by Tukey's HSD Test with $\alpha=0.05$. This treatment was carried out using SPSS v. 18.0 program.

\section{Results and Discussion}

\subsection{Synthesis of acetylated glucuronide derivatives}

$p$-Hydroxybenzoic acid (HA) was reacted with acetobromo- $\alpha$-D-glucuronic acid methyl ester (2 equiv.) affording the corresponding 2,3,4-tri- $O$-acetyl-1- $p$-hydroxybenzoyl-Dglucuronic acid methyl ester (HAGP, Figure 1) in 38\% yield after purification. 
Cinnamic acid (CA) was also reacted with acetobromo- $\alpha$-D-glucuronic acid methyl ester ( 1 equiv.) to give the corresponding 2,3,4-tri-O-acetyl-1-cinnamoyl-D-glucuronic acid methyl ester (CAGP, Figure 1) in 32\% yield after purification. The need of more equivalents of the starting glucuronic acid methyl ester in the case of HA is related with the improvement in the reaction yield; with 2 equivalents of the starting reagent we were able to double the yield of the reaction from $16 \%$ (with 1 equivalent of the starting reagent) to $38 \%$, but we also detected traces of the di-acetylated compound.

As far as we know, this is the first report on the synthesis of protected glucuronide derivatives of $p$-hydroxybenzoic and cinnamic acids, despite the existent report on the synthesis of a protected glucuronide derivative of ethyl-4-hydroxybenzoate (Zhang et al., 2012). Despite some studies describing the synthesis of glucuronide derivatives of flavonoids (Needs and Kroon, 2006; Kajjout and Rolando, 2011), we could only find one paper reporting the synthesis of ferulic acid protected glucuronide and its acyl glucuronide, with 25\% yield (Piazzon et al., 2012).

The yields obtained in the present study are quite good considering that glucuronidation reactions occur in animal metabolism, which involves the participation of specific enzymes allowing the natural occurrence of these compounds in the organism.

\subsection{Antibacterial activity}

The protected glucuronides prepared (HAGP and CAGP) were submitted to antimicrobial activity evaluation in order to compare the results with the parent acids and the mushroom extract in which they were identified. The results of antibacterial activity were presented in Table 1. G. lucidum methanolic extract was active against all the tested bacteria with minimal inhibitory concentrations of $0.0125-0.75 \mathrm{mg} / \mathrm{mL}$ and bactericidal concentrations of $0.035-1.5 \mathrm{mg} / \mathrm{mL}$. S. aureus and B. cereus were the most 
susceptible bacteria to $G$. lucidum extract, while $P$. aeruginosa was the most resistant. The extract showed higher activity against $S$. aureus and B.cereus than the antibiotics amplicillin and streptomycin. These results were better than the ones reported by Quereshi et al. (2010) and Sheena et al. (2003) that described the antibacterial activity of G. lucidum methanolic extract against $S$. aureus and B. cereus moderate and poor, respectively. The results against $P$. aeruginosa and $E$. cloacae were similar to the ones showed by ampicillin.

HA was active against all the tested bacteria with MICs of $0.003-0.03 \mathrm{mg} / \mathrm{mL}$ and MBCs of $0.007-0.06 \mathrm{mg} / \mathrm{mL}$. The majority of the tested bacteria were susceptible to HA; E. coli and L. monocytogenes were the most resistant one. HAGP also revealed a good antibacterial activity against all the tested bacteria with MICs of 0.007-0.03 $\mathrm{mg} / \mathrm{mL}$ and MBCs of $0.015-0.06 \mathrm{mg} / \mathrm{mL}$. S. typhimurium was the most susceptible to HAGP, while M. flavus, L. monocytogenes and E. coli were the most resistant bacteria to this glucuronide derivative. The antibacterial activity of HAGP decreased in comparison with the activity of its parent compound, unless for L. monocytogenes and E. coli, in which the activity was maintained. HAGP and the parent compound HA showed better activity than the extract and, even, than the standards.

CA also revealed antibacterial activity against all the tested bacteria with MICs of 0.0007-0.015 $\mathrm{mg} / \mathrm{mL}$ and MBCs of $0.0015-0.06 \mathrm{mg} / \mathrm{mL}$. It revealed an excellent activity against $P$. aeruginosa, much better than the extract, HA, HAGP and even better than the two standards tested. Curiously, P. aeruginosa was the most resistant bacteria to G. lucidum extract, but it was the most susceptible to cinnamic acid. The most resistant bacteria to the latter compound were M. flavus, L. monocytogenes and E. coli. CAGP was also active against all the tested bacteria with MICs of $0.007-0.03 \mathrm{mg} / \mathrm{mL}$ and MBCs of 0.01-0.06 mg/mL. B. cereus, S. typhimurium and E. cloacae were the 
most susceptible bacteria against CAGP, while $S$. aureus, M. flavus, L. monocytogenes and E. coli were the most resistant. Once more, the antibacterial activity of CAGP decreased in relation to the parent compound (cinnamic acid), but was better than the extract and the two standards tested.

It should be noticed that Alves et al. (2013) could not find antibacterial activity of HA and CA at $1 \mathrm{mg} / \mathrm{mL}$ against some of the herein tested bacteria: E. coli, S. aureus and $L$. monocytogenes, probably due to the different method used to screen the antimicrobial activity.

\subsection{Antifungal activity}

The antifungal activity of G. lucidum extract, prepared protected glucuronides and their parent acids was presented in Table 2 .

The extract showed antifungal activity against all the tested fungi with MICs of 0.005$1.5 \mathrm{mg} / \mathrm{mL}$ and MFCs of 0.1-4.5 mg/mL. T. viride was the most susceptible fungi to the extract while $A$. fumigatus, $A$. niger and $P$. verucosum var. cyclopium were the most resistant. In the case of $T$. viride, the extract activity was better than the one of the standards, bifonazole and ketoconazole.

HA was active against all the fungi, showing MICs of $0.003-0.12 \mathrm{mg} / \mathrm{mL}$ and MFCs of $0.015-0.25 \mathrm{mg} / \mathrm{mL}$. A. versicolor and $T$. viride were the most susceptible fungi to this phenolic acid, while A. fumigatus was the most resistant. HA showed higher activity than the extract and the two standards, for all the tested fungi.

HAGP also showed activity against all the fungi with MICs of $0.007-0.12 \mathrm{mg} / \mathrm{mL}$ and MFCs of $0.015-0.25 \mathrm{mg} / \mathrm{mL}$. This compound gave a strong activity against $A$. ochraceus, $P$. funiculosum and $P$. ochrochloron, being A. fumigatus the most resistant 
fungi. HAGP showed higher activity than the standards, the extract and even than the parent HA.

CA also has activity against all the tested fungi with MICs of $0.007-0.03 \mathrm{mg} / \mathrm{mL}$ and MFCs of $0.015-0.06 \mathrm{mg} / \mathrm{mL}$. A fumigatus was the most susceptible fungi, while $A$. niger and $P$. ochrochloron were the most resistant. This acid also gave better results than the extract and the standards, and in some cases, better than HA and HAGP.

CAGP showed antifungal activity against all the fungi with MICs of $0.007-0.06 \mathrm{mg} / \mathrm{mL}$ and MFCs of $0.015-0.25 \mathrm{mg} / \mathrm{mL}$. A. ochraceus and $P$. funiculosum were the most susceptible fungi, while $A$. fumigatus and $P$. verrucosum var. cyclopium were the most resistant. Compared with its parent $\mathrm{CA}$, the protected glucuronide maintained the activity, with the exception of $A$. niger and $P$. ochrochloron, in which the activity increased. Its antifungal activity was higher than the one revealed by the extract and the standards.

Other compounds present in G. lucidum have also been reported as antifungal, such is the case of ganodermim. Ganodermim is an antifungal protein isolated from G. lucidum with activity against phytopathogenic fungi such as Botrytis cinerea $\left(\mathrm{IC}_{50}=15.2 \mu \mathrm{M}\right)$, Fusarium oxysporum $\left(\mathrm{IC}_{50}=12.4 \mu \mathrm{M}\right)$ and Physalospora paricola $\left(\mathrm{IC}_{50}=18.1 \mu \mathrm{M}\right)$ (Wang and $\mathrm{Ng}, 2006$ ). Nevertheless, as far as we know this is the first report on antifungal activity of protected glucuronide derivatives of HA and CA.

\subsection{Demelanizing activity}

In order to investigate the demelanizing activity of $G$. lucidum extract and compounds as an important factor in fungal virulence, eight microfungi were used. Demelanizing activity was obtained only for G. lucidum extract toward A. niger. 
The results were expressed as minimum demelanizing concentrations (MDC), which were defined as sublethal and subinhibitory concentration necessary to provoke demelanization in fungus during $72 \mathrm{~h}$. The subinhibitory concentration was achieved at $0.75 \mathrm{mg} / \mathrm{mL}$, while sublethal concentration was observed at $0.1 \mathrm{mg} / \mathrm{mL}$ of G. lucidum extract (Figure 2a-f). The colored conidiophores of some Aspergillus and Penicillium species contains pigments belonging to the group of melanins: a green colored chromoprotein and a black insoluble pigment (Eisenman and Casadevall, 2012). Melanin production by fungi contributes to the virulence of pathogens of humans as well as those of food crops (Rosa et al., 2010). It was shown that this pigment has an important role in the protection of the fungus against immune effector cells; it is able to scavenge reactive oxygen species generated by alveolar macrophages and neutrophils of the host (Brakhage and Liebmann, 2005). Morphological changes in melanization of $A$. niger are obvious from Figure $\mathbf{2}$ and showed depigmentation; samples were treated with G. lucidum extracts at MDC $(0.75$ and $0.1 \mathrm{mg} / \mathrm{mL})$. Observing morphological changes of conidiphores it was determined that demelanized cultures of tested fungi interestingly possessed unusually small number of heads (Figure $\mathbf{2 a}, \mathbf{2 b}$ ) in comparison to those in untreated culture (Figure 2c). The reduction of head numbers and demelanization of $A$. niger spores is also recorded under light microscope (Figure 2d and 2e) in compurgation with untreated control (Figure 2f). Thus, we may presume that the extracts of G. lucidum might directly be involved in the inhibition or modification of the mechanism of demelanization. The results for demelanizing activity are important, since MDC is sublethal to fungus being needed smaller doses of extract, in comparison to inhibitory and fungicidal doses. 
Overall, HA, CA and their protected glucuronide derivatives (HAGP and CAGP) revealed high antimicrobial (antibacterial and antifungal) activity, even better than the one showed by commercial standards. Despite the variation in the order of parent acids and the protected glucuronide derivatives, their antimicrobial activity was always higher than the one revealed by the extract. Nevertheless, the extract was the only one with demelanizing activity against $A$. niger, which is certainly related to other compounds besides the ones mentioned in the present study. It should be highlighted that HA and CA are also present in other mushroom species and even in other matrices, which increases the general impact of the results reported herein. The synthesized acetylated glucuronide derivatives could be deprotected to obtain glucuronide metabolites, which circulate in the human organism as products of the metabolism of the parent compounds.

\section{Acknowledgements}

The authors are grateful to Fundação para a Ciência e a Tecnologia (FCT, Portugal) for financial support to the Portuguese NMR network and to FCT and FEDERCOMPETE/QREN/EU for the financial support through the research project PTDC/AGR-ALI/110062/2009 and the research centres (PEst-C/QUI/UI0686/2011 and PEst-OE/AGR/UI0690/2011). S.A. Heleno (BD/70304/2010) also thanks FCT, POPHQREN and FSE. The authors also thank to Serbian Ministry of Education and Science (grant number 173032) for financial support.

\section{References}


Alves, M.J., Ferreira, I.C.F.R., Dias, J., Teixeira, V., Martins, A., Pintado, M. (2012). A review on antimicrobial activity of mushroom (Basidiomycetes) extracts and isolated compounds. Planta Med. 78, 1707-1718.

Alves, M.J., Ferreira, I.C.F.R., Froufe, H.C., Abreu, R.M.V., Martins, A., Pintado, M. (2013). Antimicrobial activity of phenolic compounds identified in wild mushrooms, SAR analysis and docking studies. J. Appl. Microbiol. in press.

Barros, L., Dueñas, M., Ferreira, I.C.F.R., Baptista, P., Santos-Buelga, C. (2009). Phenolic acids determination by HPLC-DAD-ESI/MS in sixteen different Portuguese wild mushrooms species. Food Chem. Toxicol. 47, 1076-1079.

Brakhage, A.A., Liebmann, B. (2005). Aspergillus fumigatus conidial pigment and cAMP signal transduction: significance for virulence. Med. Mycol. 43, S75-S82.

Butler, M.S. (2004). The role of natural product chemistry in drug discovery. J. Nat. Prod. 67, 2141-2153.

Clinical and Laboratory Standards Institute (2009). Methods for dilution antimicrobial susceptibility tests for bacteria that grow aerobically. Approved standard, $8^{\text {th }}$ ed. CLSI publication M07-A8. Clinical and Laboratory Standards Institute, Wayne, PA.

Eismann, H.C., Casadevall, A. (2012). Synthesis and assembly of fungal melanin. Appl. Microbiol. Biotechnol. 93, 931-940.

Espinel-Ingrof, A. (2001). Comparison of the E-test with the NCCLS M38-P method for antifungal susceptibility testing of common and emerging pathogenic filamentous fungi. J. Clin. Microbiol. 39, 1360-1367.

Gao, Y., Tang, W., Gao, H., Chan, E., Lan, J., Li, X., Zhou, S. (2005). Antimicrobial activity of the medicinal mushroom Ganoderma. Food Rev. Int. 21, 211-222. 
Hanel, H., Raether, W. (1988). A more sophisticated method of determining the fungicidal effect of water-insoluble preparations with a cell harvester, using miconazole as an example. Mycoses 31, 148-154.

Hall, IR, Stephenson, SL, Buchanan, PK, Yun, W, Cole, ALJ. (2003). Edible and Poisonous Mushrooms of the World. Timber Press Inc., Oregon, USA, 372p.

Heleno, S.A., Barros, L., Martins, A., Queiroz, M.J.R.P., Santos-Buelga, C., Ferreira, I.C.F.R. (2012). Fruiting body, spores and in vitro produced mycelium of Ganoderma lucidum from Northeast Portugal: A comparative study of the antioxidant potential of phenolic and polysaccharidic extracts. Food Res. Int. 46, 135-140.

Heleno, S.A. Stojković, D., Glamočlija, J., Soković, M., Martins, A., Queiroz, M.J.R.P., Ferreira, I.C.F.R. (2013). A comparative study of chemical composition, antioxidant and antimicrobial properties of Morchella esculenta (L.) Pers. from Portugal and Serbia. Food Res. Int. 51, 234-243.

Kajjout, M., Rolando, C. (2011). Regiospecific synthesis of quercetin O- $\beta$-Dglucosylated and O- $\beta$-D-glucuronidated isomers. Tetrahedron 67, 4731-4741.

Lam, K.S. (2007). New aspects of natural products in drug discovery. Trend. Microbiol. $15,6279-6289$.

Lou, Z., Wang, H., Rao, S., Sun, J., Ma, C., Li, J. (2012). p-Coumaric acid kills bacteria through dual damage mechanisms. Food Control 25, 550-554.

Needs, P.W., Kroon, P.A. (2006). Convenient syntheses of metabolically important quercetin glucuronides and sulfates. Tetrahedron 62, 6862-6868.

Orhan, D.D., Özçelik, B., Özgen, S., Ergun, F. (2010). Antibacterial, antifungal, and antiviral activities of some flavonoids. Microbiol. Res. 165, 496-500. 
Oria de Rueda, J.A. (2007). Hongos y setas. Tesoro de nuestros montes. Palencia, Spain:E diciones Cálamo.

Pala, S.A., Wani, A.H. (2011). Mushrooms: The entities with multifarious medicinal properties. J. Pharm. Res. 4, 4721-4726.

Phillips, R. (1981). Mushrooms and other fungi of Great Britain and Europe. London, United Kingdom: Macmillan Publishers Ltd.

Piazzon, A., Vrhovsek, U., Masuero, D., Mattivi, F., Mandoj, F., Nardini, M. (2012). Antioxidant activity of phenolic acids and their metabolites: Synthesis and antioxidant properties of the sulfate derivatives of ferulic and caffeic acids and of the acyl glucuronide of ferulic acid. J. Agric. Food Chem. 60, 12312-12323.

Quereshi, S., Pandey, A.K., Sandhu, S.S. (2010). Evaluation of antibacterial activity of different Ganoderma lucidum extracts. J. Sci. Res. 3, 9-13.

Rechner, A.R., Kuhnle, G., Bremner, P., Hubbard G.P., Moore, K.P., Rice-Evans, C.A. (2002). The metabolic fate of dietary polyphenols in humans. Free Rad. Biol. Med. $33,220-235$.

Rosa, L.H., Vieira, L.M.A., Santiago, I.F., Rosa, C.A. (2010). Endophytic fungi community associated with the dicotyledonous plant Colobanthus quitensis (Kunth) Bartl. (Caryophyllaceae) in Antarctica. FEMS Microbiol. Ecol. 73, 178189.

Sheena, N., Ajith, T.A., Mathew, A.T., Janardhanan, K.K. (2003). Antibacterial activity of three macrofungi, Ganoderma lucidum, Navesporus floccosa and Phellinus rimosus occurring in South India. Pharmac. Biol. 41, 564-567. 
Sullivan, R, Smith, J.E., Rowan, N.J. (2006). Medicinal mushrooms and cancer therapy: Translating a traditional practice into Western medicine. Perspect. Biol. Med. 49, 159-170.

Tsukatani, T., Suenaga, H., Shiga, M., Noguchi, K., Ishiyama, M., Ezoe, T., Matsumoto, K. (2012). Comparison of the WST-8 colorimetric method and the CLSI broth microdilution method for susceptibility testing against drug-resistant bacteria. J. Microbiol. Method. 90, 160-166.

Wang, H., Ng, T.B. (2006). Ganodermin, an antifungal protein from fruiting bodies of the medicinal mushroom Ganoderma lucidum. Peptides 27, 27-30.

Zhang, Q., Raheem, K.S., Botting, N.P., Slawin, A.M.Z., Kay, C.D., O’Hagan, D. (2012). Flavonoid metabolism: the synthesis of phenolic glucuronides and sulfates as candidate metabolites for bioactivity studies of dietary flavonoid. Tetrahedron 68, 4194-4201. 
Figure 1. Glucuronidation of $p$-hydroxybenzoic and cinnamic acids. HA- $p$ hydroxybenzoic acid; HAGP- $p$-hydroxybenzoic acid glucuronide protected form; CAcinnamic acid; CAGP- cinnamic acid glucuronide protected form.

Figure 2. (a) Demelanized mycelium of A.niger treated with Ganoderma lucidum extract at $1 \mathrm{mg} / \mathrm{mL}$; (b) Mycelium of A.niger treated with G. lucidum extract at 0.75 $\mathrm{mg} / \mathrm{mL}$; (c) Normal mycelium of $A$. niger without treatment; (d) Culture of $A$. niger with few amount of heads, treated with G. lucidum extract at $0.1 \mathrm{mg} / \mathrm{mL}$; (e) Culture of A. niger with smaller amount of heads treated with G. lucidum extract at $0.75 \mathrm{mg} / \mathrm{mL}$ recorded under light microscope; (f) Typical culture of $A$. niger with numerous heads, recorded under light microscope (d-f). 
Table 1. Antibacterial activity (MIC and $\mathrm{MBC}, \mathrm{mg} / \mathrm{mL}$ ) of Ganoderma lucidum extract, $p$-hydroxybenzoic and cinnamic acids, and their synthesized acetylated glucuronide derivatives.

\begin{tabular}{|c|c|c|c|c|c|c|c|}
\hline Bacteria & $\begin{array}{c}\text { Extract } \\
\mathrm{MIC} \\
\mathrm{MBC}\end{array}$ & $\begin{array}{c}\text { HA } \\
\mathrm{MIC} \\
\mathrm{MBC}\end{array}$ & $\begin{array}{c}\text { HAGP } \\
\text { MIC } \\
\text { MBC }\end{array}$ & $\begin{array}{c}\text { CA } \\
\mathrm{MIC} \\
\mathrm{MBC}\end{array}$ & $\begin{array}{c}\text { CAGP } \\
\text { MIC } \\
\text { MBC }\end{array}$ & $\begin{array}{c}\text { Streptomycin } \\
\text { MIC } \\
\text { MBC }\end{array}$ & $\begin{array}{c}\text { Ampicillin } \\
\text { MIC } \\
\text { MBC }\end{array}$ \\
\hline Staphylococcus & 0.025 & 0.003 & 0.015 & 0.0015 & 0.03 & 0.04 & 0.25 \\
\hline aureus & 0.035 & 0.007 & 0.03 & 0.003 & 0.06 & 0.09 & 0.37 \\
\hline Bacillus & 0.0125 & 0.003 & 0.015 & 0.0015 & 0.007 & 0.09 & 0.25 \\
\hline cereus & 0.035 & 0.007 & 0.02 & 0.003 & 0.015 & 0.17 & 0.37 \\
\hline Micrococcus & 0.5 & 0.015 & 0.03 & 0.015 & 0.03 & 0.17 & 0.25 \\
\hline flavus & 0.75 & 0.03 & 0.06 & 0.03 & 0.06 & 0.34 & 0.37 \\
\hline Listeria & 0.3 & 0.03 & 0.03 & 0.007 & 0.03 & 0.17 & 0.37 \\
\hline monocytogenes & 0.75 & 0.06 & 0.06 & 0.06 & 0.06 & 0.34 & 0.49 \\
\hline Pseudomonas & 0.75 & 0.003 & 0.015 & 0.0007 & 0.007 & 0.17 & 0.74 \\
\hline aeruginosa & 1.5 & 0.007 & 0.03 & 0.0015 & 0.03 & 0.34 & 1.24 \\
\hline Salmonella & 0.35 & 0.003 & 0.007 & 0.0015 & 0.007 & 0.17 & 0.37 \\
\hline typhimurium & 0.75 & 0.007 & 0.015 & 0.003 & 0.015 & 0.34 & 0.49 \\
\hline Escherichia & 0.35 & 0.03 & 0.03 & 0.007 & 0.03 & 0.17 & 0.25 \\
\hline coli & 0.75 & 0.06 & 0.06 & 0.06 & 0.06 & 0.34 & 0.49 \\
\hline Enterobacter & 0.35 & 0.006 & 0.015 & 0.0015 & 0.007 & 0.26 & 0.37 \\
\hline cloacae & 0.75 & 0.007 & 0.03 & 0.003 & 0.01 & 0.52 & 0.74 \\
\hline
\end{tabular}

HA- $p$-hydroxybenzoic acid; HAGP- $p$-hydroxybenzoic acid glucuronide protected form;

CA- cinnamic acid; CAGP- cinnamic acid glucuronide protected form. 
Table 2. Antifungal activity (MIC and MFC, mg/mL) of Ganoderma lucidum extract, $p$ hydroxybenzoic and cinnamic acids, and their acetylated glucuronide derivatives.

\begin{tabular}{|c|c|c|c|c|c|c|c|}
\hline Fungi & $\begin{array}{c}\text { Extract } \\
\text { MIC } \\
\text { MFC }\end{array}$ & $\begin{array}{c}\text { HA } \\
\text { MIC } \\
\mathrm{MFC} \\
\end{array}$ & $\begin{array}{c}\text { HAGP } \\
\text { MIC } \\
\text { MFC }\end{array}$ & $\begin{array}{r}\text { CA } \\
\mathrm{MIC} \\
\mathrm{MFC} \\
\end{array}$ & $\begin{array}{c}\text { CAGP } \\
\text { MIC } \\
\text { MFC }\end{array}$ & $\begin{array}{c}\text { Bifonazole } \\
\mathrm{MIC} \\
\mathrm{MFC} \\
\end{array}$ & $\begin{array}{c}\text { Ketoconazole } \\
\text { MIC } \\
\text { MFC } \\
\end{array}$ \\
\hline Aspergillus & 1.5 & 0.12 & 0.12 & 0.007 & 0.03 & 0.15 & 0.20 \\
\hline fumigatus & 3.0 & 0.25 & 0.25 & 0.015 & 0.25 & 0.20 & 0.50 \\
\hline Aspergillus & 0.1 & 0.003 & 0.06 & 0.007 & 0.015 & 0.10 & 0.20 \\
\hline versicolor & 4.5 & 0.03 & 0.25 & 0.06 & 0.03 & 0.20 & 0.50 \\
\hline Aspergillus & 0.75 & 0.015 & 0.007 & 0.007 & 0.007 & 0.15 & 1.50 \\
\hline ochraceus & 1.5 & 0.07 & 0.015 & 0.03 & 0.015 & 0.20 & 2.0 \\
\hline Aspergillus & 1.5 & 0.03 & 0.015 & 0.03 & 0.015 & 0.15 & 0.20 \\
\hline niger & 3.0 & 0.07 & 0.03 & 0.06 & 0.03 & 0.20 & 0.50 \\
\hline Trichoderma & 0.005 & 0.007 & 0.007 & 0.015 & 0.015 & 0.15 & 1.0 \\
\hline viride & 0.1 & 0.015 & 0.03 & 0.03 & 0.06 & 0.20 & 1.0 \\
\hline Penicillium & 0.09 & 0.03 & 0.007 & 0.015 & 0.007 & 0.20 & 0.20 \\
\hline funiculosum & 1.5 & 0.07 & 0.015 & 0.06 & 0.015 & 0.25 & 0.50 \\
\hline Penicillium & 0.35 & 0.06 & 0.007 & 0.03 & 0.015 & 0.20 & 2.5 \\
\hline ochrochloron & 0.7 & 0.07 & 0.015 & 0.06 & 0.03 & 0.25 & 3.5 \\
\hline Penicillium & 1.5 & 0.06 & 0.03 & 0.007 & 0.06 & 0.10 & 0.20 \\
\hline verrucosum & 3.0 & 0.07 & 0.06 & 0.03 & 0.12 & 0.20 & 0.30 \\
\hline
\end{tabular}

HA- $p$-hydroxybenzoic acid; HAGP- $p$-hydroxybenzoic acid glucuronide protected form;

CA- cinnamic acid; CAGP- cinnamic acid glucuronide protected form. 
<smiles>O=C(O)c1ccc(O)cc1</smiles>

$\mathrm{HA}$<smiles>O=C(O)/C=C/c1ccccc1</smiles>

CA

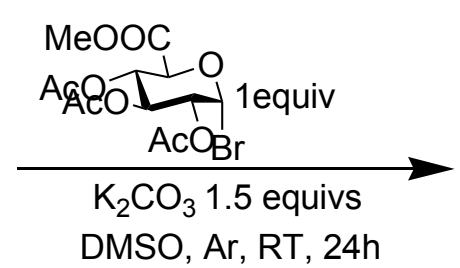

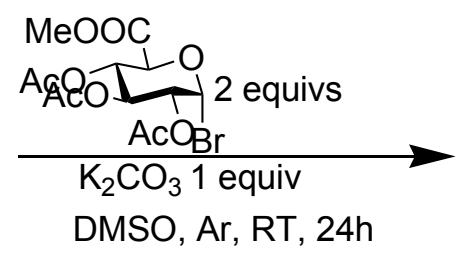

OCOACOAC

HAGP

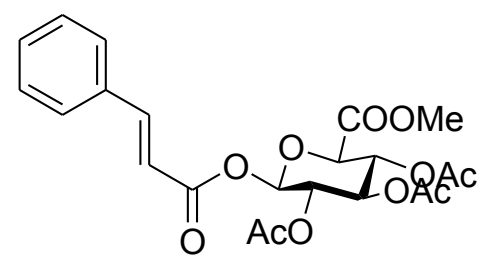

CAGP

Figure 1. Glucuronidation of $p$-hydroxybenzoic and cinnamic acids. HA- $p$ hydroxybenzoic acid; HAGP- $p$-hydroxybenzoic acid glucuronide protected form; CAcinnamic acid; CAGP- cinnamic acid glucuronide protected form. 

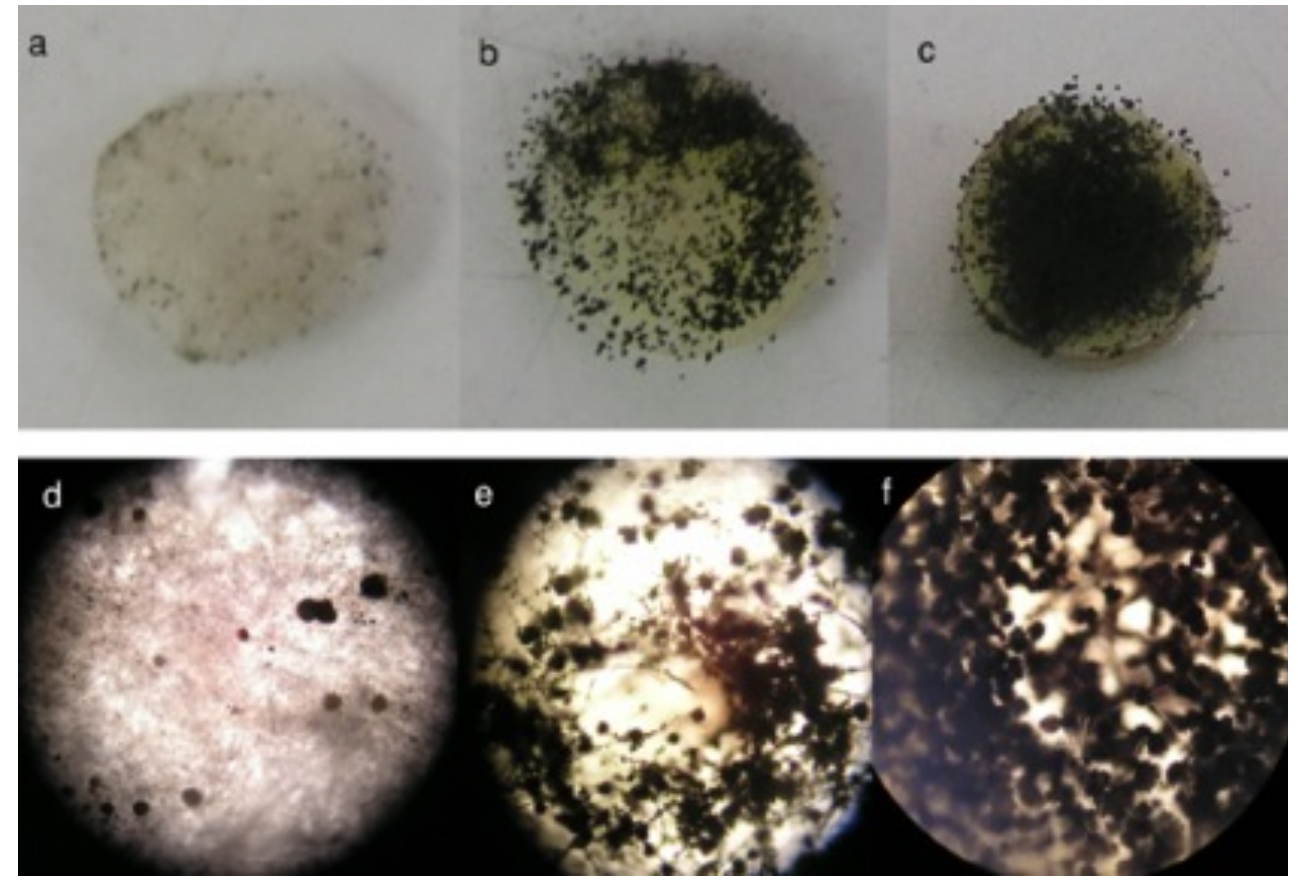

Figure 2. (a) Demelanized mycelium of A. niger treated with Ganoderma lucidum extract at $1 \mathrm{mg} / \mathrm{mL}$; (b) Mycelium of A.niger treated with G. lucidum extract at 0.75 $\mathrm{mg} / \mathrm{mL}$; (c) Normal mycelium of $A$. niger without treatment; (d) Culture of $A$. niger with few amount of heads, treated with G. lucidum extract at $0.1 \mathrm{mg} / \mathrm{mL}$; (e) Culture of A. niger with smaller amount of heads treated with G. lucidum extract at $0.75 \mathrm{mg} / \mathrm{mL}$ recorded under light microscope; (f) Typical culture of $A$. niger with numerous heads, recorded under light microscope (d-f). 